DOI: https://doi.org/10.31933/dijms.v2i3 Received: 3 November 2020, Revised: 23 December 2020, Publish: 24 January 2021

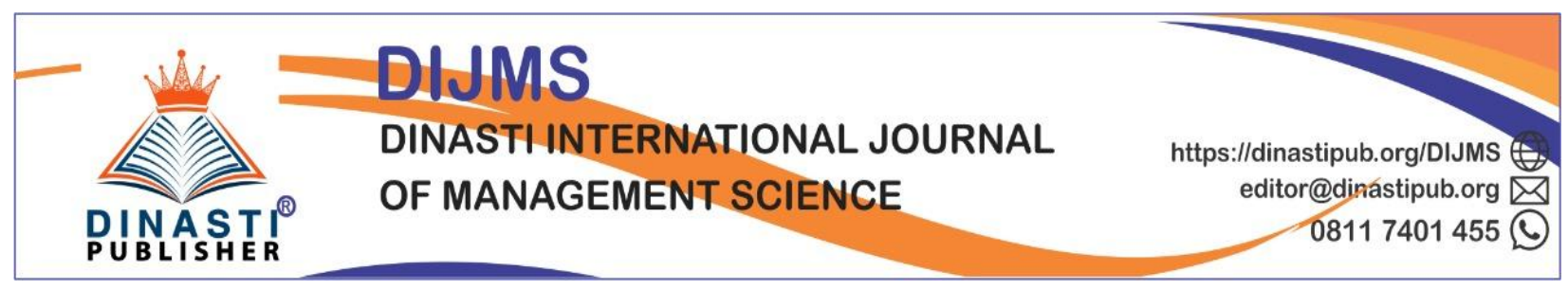

\title{
DECISION ANALYSIS OF SELECTING POSTGRADUATE PROGRAMS THROUGH PLACE, MARKETING COMMUNICATION, PRICE PERCEPTION AND SERVICE QUALITY (SURVEY OF ENGINEERING FACULTY STUDENTS AT WEST JAKARTA REGIONAL UNIVERSITY)
}

\author{
Rezza Zulfi Assakhir ${ }^{1}$, Dudi Permana ${ }^{2}$ \\ ${ }^{1)}$ Universitas Mercu Buana, Indonesia, rezazulfiumb@gmail.com \\ ${ }^{2)}$ Universitas Mercu Buana, Indonesia
}

\section{Corresponding Author: First Author}

Abstract: This study aims to analyze the decision analysis to choose a postgraduate program through Place, Marketing Communication, Price Perception and Service Quality. The results of the study using primary data in the form of questionnaires to 100 students of the Faculty of Engineering at the University of West Jakarta with the Structural Equation Modeling (SEM) method showed that Place, Marketing Communication, Price Perception and Service Quality had a positive and significant effect on the decision to choose a postgraduate program. Judging from the results of the SEM Place calculation analysis has an estimate coefficient of 0.36 or $36 \%$, Marketing Communication has an estimate coefficient of 0.15 or 15\%, Price Perception has an estimate coefficient of 0.30 or $30 \%$, Service Quality has an estimate coefficient of 0.24 or $24 \%$ influence on the decision to choose a postgraduate program. This shows that if Place, Marketing Communication, Price Perception and Service Quality have increased, it will affect the decision to choose a Postgraduate Program

Keywords: Place, Marketing Communication, Price Perception, Decision Making

\section{INTRODUCTION}

Education is very important for every individual. Education can be done using a variety of methods, namely learning the knowledge, skills and habits of a group of people who are passed down from one generation to the next through teaching, training, or research. Education is a supporting factor that plays a very important role in all sectors. Humans need education in their lives. Education is an effort so that humans can develop their potential through the learning process and / or other methods known to the community. 
Competition in the world of education is growing rapidly both in the education sector in private universities (PTS) and State (PTN) which compete with each other to attract the interest of prospective students. Various kinds of strategies are used by universities in attracting interest from the student market share. One of the private universities is Mercu Buana University. Mercu Buana University has 7 Faculties and 24 Study Programs. Mercu Buana University is one of the universities for the middle class with admission fees that continue to increase every year. The highest cost increase was in the Broadcasting study program, in the 2014/2015 academic year amounting to IDR 21.5 million, 2015/2016 amounting to IDR 26.6 million, then 2016/2017 amounting to IDR 28.5 million, and 2017/2018 it increased to IDR 31.1 million. The second highest cost is the Management and Accounting study program, for Management in the 2014/2015 school year amounting to Rp. 16.5 million, 2015/2016 amounting to Rp. 20.2 million, while for accounting in the 2014/2015 school year amounting to Rp. 16.8 million, 2015/2016 amounting to Rp. 20.6. million, then both for Management and Accounting are the same, namely 2016/2017 amounting to Rp. 23.2 million, and 2017/2018 increasing to Rp. 25.6 million. Furthermore, the cost of other study programs is smaller and the lowest is that the tuition fee for the diploma program also continues to increase from year to year which can be seen in Figure 1 below:

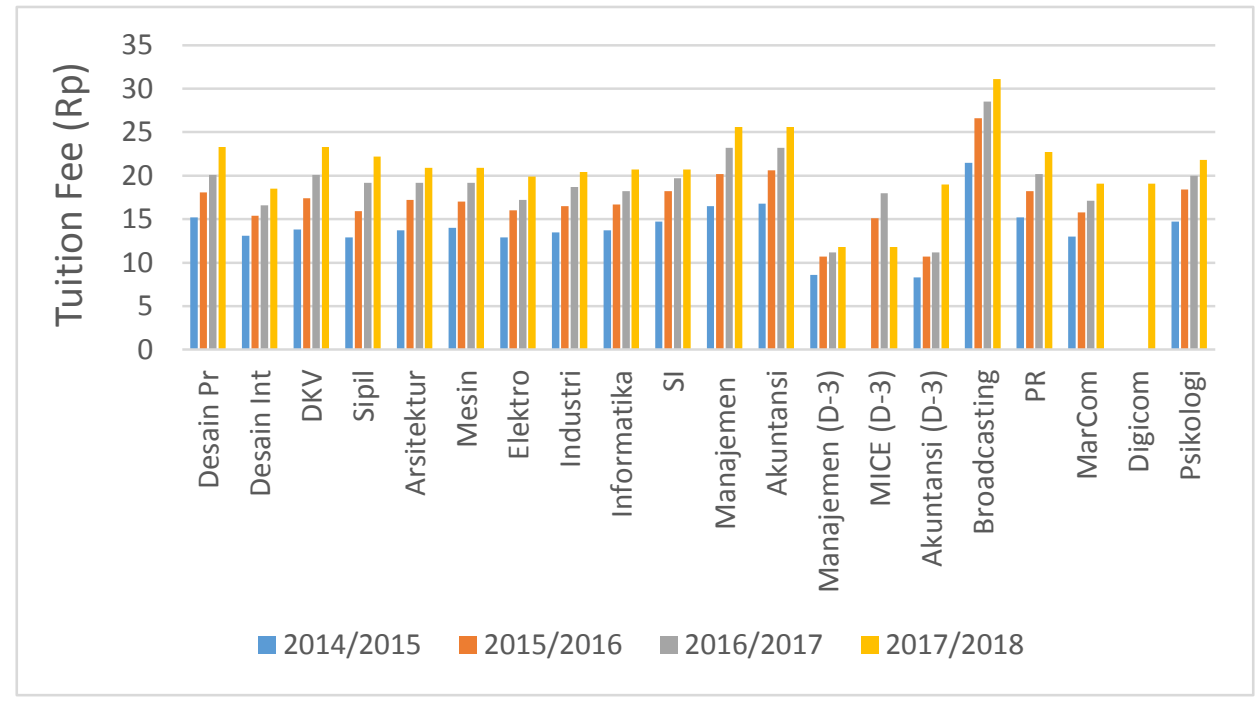

Source : Direktorat Pemasaran Reguler 1-Universitas Mercu Buana (2017)

Fig 1. Tuition Fees for Each Study Program of the Last Four Years

Data obtained from the Directorate of Regular Marketing 1 at Mercu Buana University, once distributed customer satisfaction questionnaires to 300 student parents to fill out the questionnaire, it was found that most parents saw that the payment system at UMB had advantages because it could be paid in installments, besides that most of them parents will recommend UMB as the right choice of place to study to others. Parents assess the location of the UMB campus as having a strategic location. In addition, the cost of education at UMB is classified as medium and affordable. Parents of students assess the location of the UMB campus as having a strategic location. In addition, the cost of education at UMB is classified as medium and affordable. Furthermore, the parents admit that while their sons and daughters study at UMB they are able to form a better personality and create good competence. The price factor is also one of the considerations for parents in choosing a place to study. In addition, professional 
teaching staff or lecturers, graduates meet the needs of industry and society in global competition, guaranteeing immediate employment.

The results of a survey conducted by the Marketing Directorate of Mercu Buana University show that the administrative process includes easy management and services, the cost of education at UMB is in the medium category and can be paid in installments according to ability. Good service is one of the factors that can influence parents to be loyal to UMB and make UMB a place to study at the University level for students. Mercu Buana University provides study opportunities for anyone who wants to continue their studies to a higher level. Tuition fees at UMB are classified as affordable tuition fees and UMB provides many conveniences and ways to ease the burden on student parents in making study payments, with an installment system and can be seen in Figure 2 below.

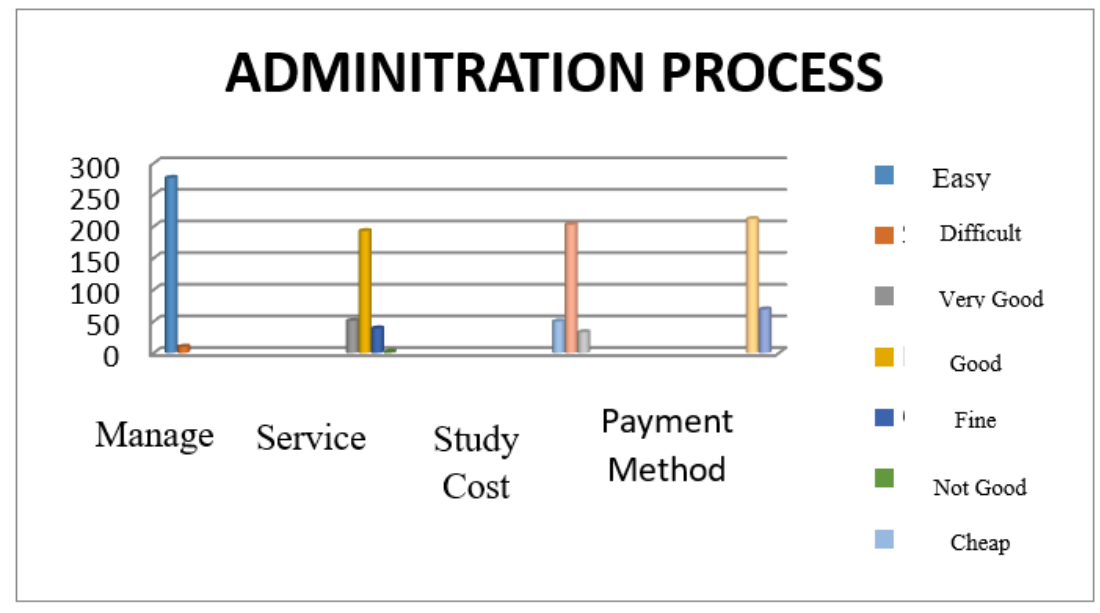

Source : Marketing Directory Reguler 1 - Universitas Mercu Buana (2017)

Fig 2. Assessment Results for Administration Processes

Postgraduate is one of the faculties owned by Mercu Buana University. A preliminary survey was also conducted on 25 respondents. The preliminary survey was carried out to find out what factors the student made as a benchmark for choosing a Postgraduate Program with the results as in the table below:

Table 1. Pre-Survei Results

\begin{tabular}{llcccc}
\hline \multirow{2}{*}{ No } & & \multicolumn{2}{c}{ Disagree } & \multicolumn{2}{c}{ Agree } \\
& & Totalement & Percentage & Total & Percentage \\
\hline 1 & Environment & 23 & $92 \%$ & 2 & $8 \%$ \\
2 & Marketing Communication & 22 & $88 \%$ & 3 & $12 \%$ \\
3 & Price Perception & 22 & $88 \%$ & 3 & $12 \%$ \\
4 & Service Quality & 20 & $80 \%$ & 5 & $20 \%$ \\
5 & Product Quality & 17 & $68 \%$ & 8 & $32 \%$ \\
6 & Brand Image & 12 & $48 \%$ & 13 & $52 \%$ \\
\hline \hline
\end{tabular}


The pre-survey results in Table 1. show that the factors of Place, Marketing Communication, price perception, Service Quality have the most influence on the Decision making the Postgraduate Program. The process of selecting a college graduate program is a big decision as parents and relatives also take part in choosing a college. This is because going to college involves a large amount of money and is also a long-term decision that will affect student life in the future. Career, friendship, social life, to the personal satisfaction of students after graduating are also taken into consideration at the beginning of choosing a college and then making the decision to go back to the same university. Based on the phenomena and the results of the preliminary survey, this research was conducted to analyze the factors that influence student decisions in choosing postgraduate programs at Mercu Buana University.

\section{LITERATURE REVIEW}

Place. Location or place is a company activity that makes products available to targets (Kotler, 2009). Place is a distribution channel, namely a series of interdependent organizations that are seen in the process of making a product or service ready for use or consumption. Location means relating to where the company should be headquartered and carry out operations. Lupiyoadi \& Hamdani (2008) states that the place in services is a combination of location and decisions on distribution channels, in this case it is related to how to deliver services to consumers and where the strategic location is. Meanwhile, Elliot et al (2012) stated that location or place is a company activity to distribute products or services that are available to consumers at the right time and place. There have been many studies related to location / place regarding purchasing decisions or consumer decisions in choosing something, one of which is research conducted by Kuyram (2013) which states that place and people have an influence on making decision making.

Marketing Communication. Communication is a social process that occurs between at least two people where someone sends a certain number of symbols to others. Meanwhile, marketing is the process of giving satisfaction to consumers to get a profit (Kotler \& Keller, 2012). It can be concluded that the notion of marketing communication is a communication activity aimed at conveying messages to consumers using a number of media and various channels that can be used with the hope of three stages of change, namely changes in knowledge, changes in attitudes, and changes in the desired actions. Kennedy (2009) suggests that marketing communication aims to achieve three stages of change aimed at consumers, namely: (!) The stage of changing knowledge, (2) the stage of changing attitudes, and (3) the stage of changing behavior. Kotler \& Keller (2012) stated that there are several factors included in marketing communication, namely: (1) advertising, (2) sales promotion, (3) public relations and publicity, (4) personal selling, and (5) direct marketing. A number of researches related to marketing communications and purchasing decisions or consumer decisions in choosing something have been carried out, among the research conducted by Sinta (2015) and Eddi \& Ida (2016) which results suggest that there is a positive and significant relationship between marketing communication and decision making.

Price Perception. costs (Kotler and Keller, 2013). Price is also the easiest element in any marketing program to customize; product features, channels, and even communications take 
more time. Price communicates the intended value positioning of the company's product or brand to the market. A well designed and marketed product can sell at a high price and generate a large profit. Perceptions of price are often identified with perceptions of quality and perceptions of costs incurred to obtain a product. Meanwhile, Assauri (2007) argues that price perception is related to how price information is fully understood by consumers and provides deep meaning for them, an approach to understanding the perception of information that has been offered so far. Several researches related to price perceptions and purchasing decisions or consumer decisions in choosing something have been carried out, including research conducted by Pungnirund (2013) and Satit et al (2011) which shows that prices influence purchasing decisions.

Service Quality. Service quality is an abstract and elusive construct because of 3 unique features related to services, namely intangibility, heterogeneity and inseparability of production \& consumption (Parasuraman, 1991). Kiew and Chee (2010) state that service quality also involves perceptions and expectations of the level of service provided to consumers to meet their needs. Meanwhile, Zeithaml (2013) states that service quality is defined as an evaluative assessment of the consumer regarding the level of excess of service performance. Service quality can be achieved if management at the top level provides leadership and demonstrates commitment (Levy and Weitz, 2012). A number of studies related to service quality and purchasing decisions or consumer decisions in choosing something have been carried out, among the research conducted by Yee and Yazdanifard (2014) \& Harjati and Venice (2015) states that there is a significant and strong relationship between service quality and purchasing decisions.

\section{RESEARCH METHODS}

This research is a research with quantitative methods and by using the method of causal analysis. The research method used in this research is the survey method. The population used in this study were students in semesters 6-8 who were active in universities in West Jakarta. Meanwhile, the sample is part of the number and characteristics of the population (Sugiyono, 2012). According to the population, the generalization area consists of objects or subjects that have certain qualities and characteristics that are determined by the researcher to study and then draw conclusions (Sugiyono, 2012). The determination of the sample size to be examined in this research uses Hair (2010), which is the number of indicators multiplied by 5, namely $18 \times 5$ with a total sample of 90 respondents. The sampling method used in this research is convenience sampling, which is a sampling technique with considerations of convenience only. Data were collected using a questionnaire. The data analysis method used in this study was SEM - Lisrel.

\section{RESULTS AND DISCUSSION Results}

This study examines the observed indicators of Voting Decisions. For validity tests that are processed in SEM all statements must have a Standardize Loading Factor (SLF) value>0.7 to be considered valid. From the results of data processing, it can be seen that the place variable has an SLF value> 0.7 so that all indicators are declared valid. Likewise for marketing communication, price perception, and service quality variables which have an SLF value <0.7, so all indicators are declared valid. The next analysis is to test the reliability of all variables using the criteria for the value of $\mathrm{CR}>0.70$ and $\mathrm{VE}>0.5$, so that it can be concluded that all variables are declared reliable in this research. After the feasibility test of the data is carried out, the next 
step is to test the suitability of the research model. The following are the results of the research model suitability test

Table 2. Research Model Fit Test Results

\begin{tabular}{lcccc}
\hline \multirow{2}{*}{ Goodnes Of Fit } & \multicolumn{2}{c}{ Marginal Fit } & \multicolumn{2}{c}{ Results } \\
\cline { 2 - 4 } Normed Chi-Square $\left(\chi^{2} / \mathrm{df}\right)$ & Good Fit & & 1.046 & Fit \\
\hline P Value & $<2.0$ & & 0.350 & Fit \\
\hline Root Mean Square Error (RMSEA) & $<0.08$ & 0.022 & Fit \\
\hline Root Mean Square Residual (RMR) & $<0.05$ & & 0.03 & Fit \\
\hline Goodness of Fit Index (GFI) & $\geq 0.90$ & $0.70<0.90$ & 0.87 & Marginal \\
\hline Normal Fit Index (NFI) & $\geq 0.90$ & $0.80-<0.90$ & 0.98 & Fit \\
\hline Non-Normed Fit Index (NNFI) & $\geq 0.90$ & $0.80-<0.90$ & 1.00 & Fit \\
\hline Comparative Fit Index (CFI) & $\geq 0.90$ & $0.80-<0.90$ & 1.00 & Fit \\
\hline Increamental Fit Index (IFI) & $\geq 0.90$ & $0.80-<0.90$ & 1.00 & Fit \\
\hline Relative Fit Index (RFI) & $\geq 0.90$ & $0.80-<0.90$ & 0.98 & Fit \\
\hline
\end{tabular}

It can be seen in the table above that the measurement model test shows that the overall model fit value has shown a fit value. Because the measurement model test has Good Fit and does not need to be modified, the analysis is continued to the structural model test, which results will be the same as the measurement model test in the table above.

After obtaining a structural model with a good Goodness of Fit, the next step is to test the hypothesis. In this study, there are 5 hypotheses as previously described and the significance of each variable relationship was tested. The significance value $(\alpha)$ used is 0.05 or $5 \%$ with a $t$ value of $\geq 1.96$ (Wijanto, 2008). The estimated value of the causal relationship from the structural model tested and the results of hypothesis testing by looking at the $t$ value in the relationship between variables and can be seen in the following table (information: said to be influential if the t-value $\geq 1.96$ ) is as follows:

Table 3. Hypothesis Test

\begin{tabular}{lccc}
\hline \multicolumn{1}{c}{ Relations Between Constructs } & Estimates & T-Values & Information \\
\hline Place-> Decision Making & 0.36 & 3.77 & Positif and Significant \\
\hline $\begin{array}{l}\text { Marketing Communication -> } \\
\text { Decision Making }\end{array}$ & 0.15 & 2.51 & Positif and Significant \\
\hline \begin{tabular}{l} 
Price Perception -> Decision Making \\
\hline
\end{tabular} & 0.30 & 2.27 & Positif and Significant \\
\hline
\end{tabular}




\begin{tabular}{llll}
\hline Service Quality -> Decision Making & 0.24 & 2.25 & Positif and Significant \\
\hline
\end{tabular}

\section{Discussion}

Place has a positive and significant effect directly on the Decision making a graduate program. In other words, if Place has increased it will influence the Decision making a College Postgraduate Program. The results of this study also confirm the results of research from Murwatiningsih (2014) and Kuyram (2013) which state that Place has an effect on making decisions making.

Marketing Communication has a positive and significant effect directly on the Decision making a Postgraduate Program. In other words, if Marketing Communication has increased, it will affect the Decision making a Postgraduate Program. The results of this study also confirm the research results of Sinta (2015) \& Eddi and Ida (2016). The results obtained from this study are that marketing communication affects purchasing decisions.

Price perception has a positive and significant effect directly on the Decision making a postgraduate program. In other words, if the price perception increases, it will affect the Decision making a tertiary education postgraduate program. The results of this study also confirm the research results of Pungnirund (2013) \& Rani and Tjiptono. (2016) whose results show that costs influence the Decision making.

Service Quality has a positive and significant effect directly on the Decision making a Postgraduate Program. In other words, if the quality of service has increased, it will affect the Decision making a postgraduate program. The results of this study also confirm the research results of Yee and Yazdanifard (2014) and Zhafira et al (2013), which show that service quality influences the Decision making.

Several research operational variables that can be assigned to each university, especially postgraduate study programs, are that universities are expected to provide information on easy access to transportation, as well as the small amount of information related to exhibitions and demonstrations that reach consumers based on research results that are the attention of universities to be improved. Besides, information on prices and as well as trust in choosing universities to be easier to understand and to improve service quality to meet consumer needs.

\section{CONLUSION AND SUGGESTION}

\section{Conlusion}

a. Place has a positive and significant effect on the Decision making a Graduate College Program. This means that it can be interpreted that Place increases so that it can increase the Decision making a Postgraduate Program.

b. Marketing Communication has a positive and significant effect on the Decision making a Postgraduate Program. This means that increasing Marketing Communication can increase the Decision making a Postgraduate Program.

c. Price Perception has a positive and significant effect on the Decision making a Postgraduate Program. This means that the perception of price increases, so it can increase the Decision making a Postgraduate Program. 
d. Service Quality has a positive and significant effect on the Decision making a Postgraduate Program. This means that it means that the quality of service increases, so it can increase the Decision making a postgraduate program.

\section{Suggestions}

a. Suggestions that can be taken into consideration are to disseminate the easiest and best public information for consumers regarding access and public transportation through advertisements, social media or directly in public places or to potential consumers, making it easier for consumers to get information and could more easily choose to come to college.

b. Increased promotion in public places that have the potential to be visited so that information related to postgraduate programs becomes easy to obtain, such as exhibitions in malls or in public places that are widely visited.

c. Higher education institutions need to provide an overall understanding of the price information provided related to facilities and teaching methods, so as to provide a service meaning from the price list that has been given in each postgraduate study program.

d. Higher education needs to improve the quality of each organization or division it has, such as service, product quality, transportation information, promotions and information about the university to be more superior in the eyes of consumers.

e. Researchers can then carry out research by adding variables related to the Decision making a tertiary education postgraduate program, such as the influence of products, competence, community service and so on and can carry out research in other universities.

f. Subsequent research can also expand the research location, increase the number of samples, and seek alternative research and measurement methods to the Decision Analysis of Choosing a Graduate College Program, such as adding experimental methods, so that it can provide a more complete and comprehensive picture.

\section{REFERENCES}

Adisaputro, Gunawan. (2014). Manajemen Pemasaran (Analisis Untuk Perancangan Strategi Pemasaran). UPP STIM YKPN. Yogyakarta.

Aaker David. A, dan Joachimstahler, 2009, Brand Equity and Advertising, alih Bahasa; Aris Ananda. Edisi III, MitraUtama, Jakarta.

Anaza, Nwamaka A. and Brian Rutherford. (2014). Increasing Business-To-Business Buyer Word-of-Mouth and Share-of-Purchase. Journal of Business \& Industrial Marketing 29/5 (2014) 427-437.

Assauri, Sofjan. (2007). Manajemen Pemasaran. Jakarta: Rajawali Gramedia Pustaka Utama Buchari. Alma. (2007). Manajemen Pemasaran dan Pemasaran Jasa, Alfabeta, Bandung Duygun, Adnan dan Bunyamin Topcu. (2015). The Impacts of Customer Loyalty on Negative Word-of-Mouth Communication and Repurchase Intention. Marmara University, Istanbul/Turkey. Journal of Marketing and Management, 6 (1), 16-27.

Ghozali, Imam. (2013). Structural Equation Modeling. Teoeri, Konsep dan Aplikasi dengan Program Lisrel 9.10. Penerbit Universitas Diponegoro. Semarang.

Havidz, H. B. H., \& Mahaputra, M. R. (2020). BRAND IMAGE AND PURCHASING DECISION: ANALYSIS OF PRICE PERCEPTION AND PROMOTION 
(LITERATURE REVIEW OF MARKETING MANAGEMENT). Dinasti International Journal of Economics, Finance \& Accounting, 1(4), 727-741.

Hendi Ariyan. (2013). Pengaruh Brand Awareness dan Kepercayaan Konsumen Atas Merek Terhadap Keputusan Pembelian Ulang Minuman Aqua di Kota Padang. Jurnal. Fakultas Ekonomi, Universitas Negeri Padang.

Hoskins, Jim. (2007). Word of Mouth Research: Principals and Applications. The Journal of Advertising Research, ARF.

Jalilvand, Mohammad R. dan Neda S. (2012). The effect of electronic word of mouth on brand image and purchase intention An empirical study in the automobile industry in Iran. Marketing Intelligence \& Planning Vol. 30 No. 4, pp. 460-476.

Kotler,Philip. dan Keller, Kevin Lane. (2012). Manajemen Pemasaran. Diterjemahkan oleh Sabran. Bob. Edisi tiga belas. Jilid 1, Penerbit Erlangga. Jakarta.

(2013). Manajemen Pemasaran. Diterjemahkan oleh Sabran. Bob. Edisi tiga belas. Jilid 2, Penerbit Erlangga. Jakarta.

Lee, Yi-Chih., Wei-Li Wu. (2014). The Effect of Word-of-Mouth, Knowledge, and Promotions on Purchase Intention of Medical Cosmetics. The International Journal of Organizational Innovation Vol 6 Num 3.

Lo, Sheng Ch. (2012). Consumer Decisions: The Effect of Word-Of-Mouth. Department of Travel Management,Tourism Hospitality School, Hsing Wu Institute of Technology, Taiwan. The International Journal of Organizational Innovation Vol 4 Num 3.

Lumpioyadi, Rambat dan Hamdani A. (2006). Manajemen Pemasaran Jasa, , Penerbit Salemba Empat, Jakarta.

Mahaputra, M. R. (2020). BUILDING TRUST THROUGH SERVICES QUALITY AND BRAND IMAGE TOWARDS DECISION IN CHOOSING FINANCIAL INSTITUTION AT PT. SUMMIT OTO FINANCE (CASE STUDY PT. SUMMIT OTO FINANCE KEDOYA BRANCH, WEST JAKARTA). Dinasti International Journal of Education Management And Social Science, 2(2), 231-241.

Mowen, John C; Michael Minor. (2010). Consumer Behavior. Alih Bahasa Dwi Kartini Yahya. Penerbit Erlangga. Jakarta.

Nouri, Bagher A. dan Milad S. (2015). Evaluating The Effect of Tourism Marketing Mix on Buying Holiday Homes in Cyprus. Deparment of Management, Faculty of Humanities, University of Mohaghegh Ardabili, Ardabil, Ira. School of Business Management, European University of Cyprus, Nicosia, Cyprus. International Journal of Business Administration Vol. 6, No. 5.

Onigbinde, Isaac O, dan Odunlami, S.A. (2015). The influence of brand image and promotional mix on Consumer buying decision- a study of beverage consumers in Lagos State, Nigeria. British Journal of Marketing Studies. Vol.3, No.4, pp.97-109.

Pungnirund, B. (2013). The Influences of Marketing Mix on Customer Purchasing Behavior at Chatuchak Plaza Market World Academy of Science, Engineering and Technology. International Journal of Social, Behavioral, Educational, Economic, Business and Industrial Engineering Vol: 7, No: 8.

Rangkuti, F. (2002). The Power Of Brand. Jakarta : Gramedia Pustaka Utama

Rani Septhevian dan Fandy Tjiptono. (2016). Faktor-Faktor yang Mempengaruhi Keputusan Orangtua Dalam Memilih Sekolah Dasar. Program Studi Manajemen. Program Pascasarjana Universitas Atma Jaya Yogyakarta. Artikel Progam Sudi Manajemen. Program Pascasarjana Universitas Atma Jaya Yogyakarta. 
Sanusi, Anwar. (2011). Metodologi Penelitian Bisnis, Penerbit Salemba Empat, Jakarta.

Satit, Rezky Purna, Huam Hon Tat, Amran Rasli, Thoo Ai Chin and Inda Sukati. (2012). The Relationship Between Marketing Mix and Customer Decision-Making Over Travel Agents: An Empirical Study. Faculty of Management and Human Resource Development, Universiti Teknologi Malaysia. International Journal of Academic Research in Business and Social Sciences, Vol.2, No. 6.

Schiffman, Leon G. and Leslie Lazar Kanuk. (2012), Consumer Behaviour, alih Bahasa Zoelkifli Kasip, Indeks. Jakarta.

Sekaran, Uma. (2010). Research Methods for Business. Penerbit Salemba Empat. Jakarta.

Setiadi, Nugroho J. (2013). Perilaku Konsumen, Perspektif Kontemporer pada Motif, Tujuan, dam Keinginan Konsumen. Kencana Prenada Media. Jakarta.

Singgih, Santoso. (2011). Structural Equation Modeling (SEM), Konsep dan Aplikasi dengan AMOS 18. Penerbit Elex Media Komputindo. Jakarta.

Sitorus, Tigor dan Roni Hartono. (2015). Efek Mediasi Custommer Trust atas Pengaruh Word of Mouth, Perceived Quality, Brand Image terhadap Purchase Intention (Study empiris atas permintaan Personal Computer di wilayah Jakarta. Journal of Business Applied Management. Vol 8, No 2.

Sri Rahayusih Wilujeng dan Muhammad Edwar.. 2015. Pengaruh Brand Awareness dan Brand Trust terhadap Keputusan Pembelian Produk Oriflame. Jurnal Ekonomi. Fakultas Ekonomi, Universitas Negeri Surabaya.

https://www.4icu.org/id/ Top Universities in Indonesia. (diunduh pada 4 Nopember 2017).

Muliadin. (2016). Pengaruh atribut produk, persepsi harga, aktivitas distribusi dan promosi terhadap keputusan pembelian smarphone Samsung (Studi kasus pada Mahasiswa Magister Manajemen Reguler 2 Universitas Mercu Buana). Tesis. Program Studi Magister Manajemen Universitas Mercu Buana.

Sudaryono. (2014). Perilaku Konsumen Dalam Prespektif Pemasaran. Jakarta: Lentera Ilmu Cendekia.

Sugiyono. 2013. Metode Penelitian Bisnis, Alfabeta. Bandung.

Sumarwan, U. (2011). Perilaku Konsumen: Teori dan Penerapannya dalam Pemasaran. Penerbit Ghalia Indonesia. Jakarta.

Sunyoto, D. (2013). Dasar-Dasar Manajemen Pemasaran, Cetakan Pertama, Caps. Yogyakarta.

Supranto, J dan Limakrisna, N. (2010). Statistik Ekonomi \& Bisnis, Penerbit Mitra Wacana Media. Jakarta.

Tjiptono, Fandy dan Chandra, Gregorius. (2012). Manajemen Strategik, Andi Yogyakarta

Wijanto, Setyo, Hari. (2015). Metode Penelitian Menggunakan Structural Equation Model, Lisrel 9. Lembaga Penerbit FEUI. Jakarta.

www.antaranews.com Perguruan Tinggi harus Memiliki Branding yang Baik. (diunduh pada 12 Nopember 2017).

www.artikelind.com. Biaya Perguruan Tinggi. (diunduh pada 12 Oktober 2017)

www.parenting.co.id Pendidikan Perguruan Tinggi bagi putra-putri. (diunduh pada 12 Nopember 2017).

Zhafira, Nabila H., Junio A, Sheila S A dan Suresh K. (2013). The Analysis of Product, Price, Place, Promotion and Service Quality on Customers' Buying Decision of Convenience Store: A Survey of Young Adult in Bekasi, West Java, Indonesia President Business School, Jababeka Educational Park, Jababeka, Cikarang, Indonesia. International Journal of Advances in Management and Economics Vol.2.72-78. 